\title{
Pembentukan Karakter Rasa Ingin Tahu Melalui Kegiatan Literasi
}

\author{
Carolina Hidayah Citra Ningrum ${ }^{1}$, Khusnul Fajriyah ${ }^{2}$, M. Arief Budiman ${ }^{3}$ \\ ${ }^{123}$ PGSD Fakultas IImu Pendidikan Universitas PGRI Semarang \\ e-mail: Citraningrum47@gmail.com ${ }^{1}$, Khusnulfajriyah@upgris.ac.id ${ }^{2}$, \\ ariefbudiman@upgris.ac.id ${ }^{3}$
}

\begin{abstract}
Abstrak
Pembentukan Karakter Rasa Ingin Tahu Melalui Kegiatan Literasi Pada Siswa Kelas V SD Negeri Klampok 01 Brebes. Tujuan Penelitian ini untuk mendeskripsikan dan menganalisis pembentukan karakter rasa ingin tahu melalui kegiatan literasi pada siswa kelas V SD N Klampok 01 Brebes. Jenis Pendekatan yang digunakan penelitian ini yaitu pendekatan kualitatif jenis deskriptif. Sampel yang diambil adalah seluruh siswa kelas V. Data hasil angket yang telah diisi oleh responden dapat dilihat hasil tertinggi sebesar $86,7 \%$ yaitu siswa menjawab "Tidak Pernah" pada pernyataan ke 14 "Saya tidak peduli saat wilayah brebes terkena musibah", dan pernyataan ke 18 "Saya lebih memilih bermain dan tidak peduli jika ada teman yang kesusahan". Pembentukan karakter rasa ingin tahu melalui kegiatan literasi di SD N Klampok 01 Brebes dapat disimpulkan bahwa kegiatan literasi yang dilaksanakan di SD N Klampok 01 Brebes sudah dilaksanakan dengan baik dan sudah membentuk karakter rasa ingin tahu siswa. Hal ini dapat dilihat dari perkembangan karakter siswa yang sudah meningkat dan dilihat dari empat indikator karakter rasa ingin tahu sudah memperoleh persentase cukup tinggi.
\end{abstract}

Kata Kunci : karakter rasa ingin tahu, kegiatan literasi

\begin{abstract}
The development of Curiosity Character through Literacy Activities in fifth Students of SD Negeri Klampok 01 Brebes. The purpose of this study was to describe and analyze the formation of the character of curiosity through literacy activities in fifth grade students of SD N Klampok 01 Brebes. The type of approach that used in this research was descriptive qualitative approach. Samples were all of fifth grade students. Questionnaire results that have been filled out by respondents can be seen the highest results of $86.7 \%$ ie students answered "Never" in the 14th statement "I do not care when the brebes area was affected by disaster", and the statement 18 "I prefer to play and do not care if there are friends who are distressed" The formation of the character of curiosity through literacy activities at SD N Klampok 01 Brebes can be concluded that the literacy activities carried out at SD N Klampok 01 Brebes have been carried out well and have formed the character of students' curiosity. It can be seen from the development of the character of students who have increased and seen from the four indicators of curiosity character has been fairly high percentage.
\end{abstract}

Keywords: curiosity character, literacy activities 


\section{Pendahuluan}

Menurut Undang-Undang Sistem Pendidikan Nasional No.20 Tahun 2003 pasal 1 butir 1, pendidikan adalah: "usaha sadar dan terencana untuk mewujudkan suasana belajar dan proses pembelajaran agar peserta didik secara aktif mengembangkan potensi dirinya untuk memiliki kekuatan spiritual keagamaan, pengendalian diri, kepribadian, kecerdasaan, akhlak mulia, serta keterampilan yang diperlukan dirinya, masyarakat, bangsa dan Negara." Pendidikan nasional bertujuan: "untuk mengembangkan potensi peserta didik agar menjadi manusia yang beriman dan bertakwa kepada Tuhan Yang Maha Esa, berakhlak mulia, cakap, kreatif, mandiri, dan menjadi waarga Negara yang demokratis serta bertanggung jawab" (UU Sisdiknas No. 20 tahun 2003 pasal 3) (Ayu, 2017).

Pendidikan karakter adalah suatu sistem penamaan nilai-nilai karakter yang meliputi komponen pengetahuan, kesadaran atau kemauan, dan tindakan untuk melaksanakan nilainilai tersebut, baik terhadap Tuhan Yang Maha Esa, diri sendiri, sesama, lingkungan, maupun kebangsaan. Pengembangan karakter bangsa dapat dilakukan melalui perkembangan karakter individu seseorang.Akan tetapi, karena manusia hidup dalam lingkungan sosial dan budaya tertentu, maka perkembangan karakter individu seseorang hanya dapat dilakukan dalam lingkungan sosial dan budaya yang bersangkutan. Artinya, perkembangan budaya dan karakter dapat dilakukan dalam suatu proses pendidikan yang tidak melepaskan peserta didik dari lingkungan sosial,budaya masyarakat, dan budaya bangsa.Lingkungan sosial dan budaya bangsa adalah Pancasila, jadi pendidikan budaya dan karakter adalah mengembangkan nilainilai Pancasila pada diri peseta didik melalui pendidikan hati, otak, dan fisik (Omeri, 2015).

Formal Saat ini kita sudah memasuki abad 21, abad dimana berbagai informasi dapat diperoleh semua orang di penjuru dunia tanpa terkecuali. IImu Pengetahuan dan Teknologi (IPTEK) juga berkembang begitu pesat, kini tak ada batasan ruang dan waktu lagi bagi tiap manusia untuk mencari informasi dan berkomunikasi. Pesatnya perkembangan IPTEK berimbas pada tantangan dan persaingan global yang dihadapi oleh setiap negara, khususnya Indonesia. Terciptanya sumber daya manusia yang berkualitas sangat diperlukan untuk mengatasi tantangan dan persaingan global tersebut. Adanya sumber daya manusia berkualitas diharapkan mampu untuk berkompetisi dengan masyarakat luas, khususnya di dunia pekerjaan. Pendidikan merupakan alternatif utama untuk mempersiapkan generasi penerus yang siap berkompetisi di abad 21.

Guna mempersiapkan kompetisi di abad 21, peningkatan mutu pendidikan sangatlah diperlukan untuk menghadapi persaingan di era globalisasi. Salah satu upaya konkret yang dilakukan oleh pemerintah Indonesia ialah dengan membenahi atau penyempurnaan kurikulum pendidikan yang berlaku. Dalam kurikulum 2013 menekankan bahwa peserta didik tidak hanya pintar dalam pelajaran saja melainkan sifat maupun karakter dari peserta didik perlu ditingkatkan melalui pendidikan yang ada.

Pendidikan sendiri merupakan hal yang sangat penting dan berguna bagi diri manusia, tidak ada seorang pun yang dilahirkan di dunia ini tiba-tiba langsung pandai dan terampil dalam memecahkan masalah kehidupannya tanpa melalui proses pendidikan, karena pada dasarnya pendidikan merupakan sistem atau cara meningkatkan kualitas hidup manusia dalam segala aspek kehidupanya.

Melalui proses pendidikan inilah manusia memperoleh bimbingan, pengalaman, pengertian, serta pandangan yang menyebabkan seorang berfikir untuk lebih maju. Tujuan dari pada Pendidikan merupakan wujud usaha bentuk kegiatan manusia dalam kehidupanya serta menempatkan tujuan sebagai sesuatu yang hendak di capai, baik yang di rumuskan itu bersifat abstrak maupun rumusan-rumusan yang di bentuk secara khusus untuk memudahkan pencapaian tujuan yang hendak di capai. Sedangkan, menurut Undang-Undang Nomor 20 tahun 2003 tentang Sistem Pendidikan Nasional, Pasal 3, tujuan pendidikan nasional adalah mengembangkan potensi peserta didik agar menjadi manusia yang beriman dan bertakwa kepada Tuhan Yang Maha Esa, berakhlak mulia, sehat, berilmu, cakap, kreatif, mandiri, dan menjadi warga negara yang demokratis serta bertanggung jawab.

Aspek yang menjadi fokus utama dari kegiatan pembelajaran Sekolah Dasar berdasarkan tujuan pendidikan nasional adalah pembentukan karakter. Kegiatan pembentukan karakter tersebut kemudian dikenal dengan pendidikan karakter. Zainuddin ( 2013:23) dalam Ryan A, dkk ( 2017:28 ) mengemukakan pendidikan karakter diartikan sebagai usaha yang sungguh-sungguh untuk memahami, membentuk, memupuk nilai-nilai etika, baik untuk diri sendiri maupun untuk warga masyarakat atau warga negara secara keseluruhan. 
Berdasarkan Kemendiknas (2010:9-10) ada 18 karakter yang perlu dikembangkan oleh siswa yaitu : religius, jujur, toleransi, disiplin, kerja keras, kreatif, mandiri, demokratis, rasa ingin tahu, semangat kebangsaan, cinta tanah air, menghargai prestasi, bersahabat/komunikatif, cinta damai, gemar membaca, peduli lingkungan, peduli sosial, dan tanggung jawab. Salah satu nilai karakter bangsa yang dirumuskan oleh Kemendiknas adalah nilai karakter rasa ingin tahu.

Rasa ingin tahu merupakan titik awal dari pengetahuan yang dimiliki oleh manusia. Sesuai dengan pernyataan Suriasumantri (2007) dalam Puspitasari MT, dkk (2015: 033) bahwa pengetahuan dimulai dari rasa ingin tahu. Rasa ingin tahu terjadi karena siswa menganggap bahwa sesuatu yang dipelajari merupakan hal yang baru yang harus diketahui untuk menjawab ketidaktahuannya. Sedangkan menurut Silmi dan Kusmarni (2017:232-234) Rasa ingin tahu adalah suatu emosi alami yang ada pada dalam diri manusia yang mana adanya keinginan untuk menyelidiki dan mencari tahu lebih dalam mengenai suatu hal yang dipelajarinya. Rasa ingin tahu akan membuat siswa terus menerus mencari tahu mengenai apa yang tidak ia ketahui, dengan mencari tahu siswa akan mendapatkan banyak informasi serta ilmu yang baru dan menambah wawasan yang ia punya.

Untuk meningkatkan rasa ingin tahu peserta didik, diadakan kegiatan literasi yang diharapkan dapat mengembangkan karakter. Abidin Y, dkk (2018:1) mengungkapkan bahwa Literasi didefinisikan sebagai kemampuan untuk menggunakan bahasa dan gambar dalam bentuk yang kaya dan beragam untuk membaca, menulis, mendengarkan, berbicara, melihat, menyajikan, dan berfikir kritis tentang ide-ide. Menurut Kamus Besar Bahasa Indonesia (KBBI) Literasi yaitu kemampuan menulis dan membaca, pengetahuan atau keterampilan dalam bidang atau aktivitas tertentu dan kemampuan individu dalam mengolah informasi dan pengetahuan untuk kecakapan hidup.

Berdasarkan studi pendahuluan yang dilakukan di SD Negeri Klampok 01 Brebes dengan narasumber Ibu Kepala Sekolah Sopiyah Ginawati, S.Pd melalui wawancara diperoleh fakta bahwa karakteristik rasa ingin tahu memang sangat penting dibangun pada diri siswa, dengan siswa memiliki rasa ingin tahu yang tinggi pembelajaran di kelas akan semakin produktif. Kemudian dengan siswa sering bertanya kelas menjadi hidup dan siswa juga dapat mengetahui hal yang mereka belum tahu. Namun saat melakukan wawancara dengan Guru Kelas VB Ibu Umayah,S.Pd.SD rasa ingin tahu siswa kelas VB di SD N Klampok 01 Brebes dengan siswa yang berjumlah 22 masih sangat rendah, siswa masih malu untuk bertanya saat pembelajaran berlangsung, hanya beberapa siswa saja yang sudah mulai berani mengajukan pertanyaan. Mengenai kegiatan literasi ibu kepala sekolah Sopiyah Ginawati, SPd mengatakan bahwa kegiatan literasi yang dilakukan di SD Klampok 01 ini sudah dilaksanakan dengan baik tetapi memang perlu diperbaiki agar lebih baik lagi.

Beberapa guru cenderung hanya menyuruh siswa untuk membaca sebuah cerita saja, ada salah satu guru yang melakukan kegiatan literasi dengan menampilkan sebuah video, dan siswa diminta menanggapi isi dari video tersebut, disitu siswa sangat antusias. Siswa juga lebih tertarik ketika pembelajaran dilakukan di perpustakaan dengan siswa diberi kebebasan dalam memilih buku bacaan yang ingin di baca dan siswa diminta untuk menceritakannya kembali. Kegiatan literasi yang ada di sekolah SD Negeri Klampok 01 Brebes dilaksanakan di dalam kelas. Pelaksanaannya 15 menit sebelum pembelajaran dimulai.

Menurut Piaget dalam Setianingsih dkk (2018:52-53) " karakteristik siswa sekolah dasar pada usia 7-12 tahun masuk dalam tahap Contrete Operational (operasional konkret) dimana pada tahap ini anak mengembangkan pemikiran logis, tetapi masih terbatas pada objek-objek konkrit, dan mampu melakukan konservasi. Jadi pada kemampuan ini siswa masih membutuhkan benda-benda yang konkrit untuk mengembangkan kemampuan intelektualnya".

Berdasarkan uraian latar belakang di atas, maka peneliti perlu melakukan penelitian yang berjudul "Pembentukan Karakter Rasa Ingin Tahu Melalui Kegiatan Literasi Pada Siswa Kelas V SD Negeri Klampok 01 Brebes".

Tujuan penulisan artikel ini adalah untuk mendeskripsikan dan menganalisis pembentukan karakter rasa ingin tahu melalui kegiatan literasi pada siswa kelas V SD N Klampok 01 Brebes.

Pendidikan karakter menurut Kesuma dharma dkk (2012:5-6) dapat diartikan pembelajaran yang mengarah pada penguatan dan pengembangan perilaku anak secara utuh yang didasarkan pada suatu nilai tertentu yang dirujuk oleh sekolah. Definisi ini mengandung makna yaitu yang pertama pendidikan karakter merupakan pendidikan yang terintegrasi dengan pembelajaran yang terjadi pada semua mata pelajaran, yang kedua diarahkan pada penguatan dan pengembangan perilaku anak secara utuh. Asumsinya anak merupakan organisme 
manusia yang memiliki potensi untuk dikuatkan dan dikembangkan. Yang ketiga penguatan dan pengembangan perilaku didasari oleh nilai yang dirujuk sekolah.

Thomas Likona dalam Muslich M(2011:29) pendidikan karakter adalah pendidikan budi pekerti plus, yaitu yang melibatkan aspek teori pengetahuan (cognitive), perasaan (feeling), dan tindakan (action). Menurutnya tanpa ketiga aspek ini, maka pendidikan karakter tidak akan efektif, dan pelaksanaannya pun harus dilakukan secara sistematis dan berkelanjutan. Dengan pendidikan karakter, seorang anak akan menjadi cerdas emosinya. Kecerdasan emosi adalah bekal terpenting dalam mempersiapkan anak menyongsong masa depan.

Berdasarkan beberapa teori di atas dapat diketahui bahwa pendidikan karakter merupakan sistem untuk menanamkan nilai-nilai kebaikan yang menyangkut karakter yang dilaksanakannya melibatkan semua pihak baik keluarga, sekolah maupun masyarakat luas. Yang melaksanakan pendidikan karakter di sekolah tidak hanya peserta didik melainkan guru, kepala sekolah, staf sekolah, penjaga sekolah dan warga sekolah lain yang ikut berperan melaksanakan pendidikan karakter.

Menurut Syarbini A (2017:53) fungsi pendidikan karakter dapat dilihat dari tiga sudut pandang: (1) Fungsi pembentukan dan pengembangan potensi, yaitu pendidikan karakter berfungsi membentuk dan mengembangkan potensi manusia dan warga negara Indonesia agar berpikiran baik, berhati baik, dan berperilaku baik. (2) Fungsi perbaikan dan penguatan, yaitu pendidikan karakter berfungsi memperbaiki dan memperkuat peran keluarga,satuan pendidikan, masyarakat dan pemerintah untuk ikut berpartisipasi dan bertanggung jawab dalam pengembangan potensi warga negara dan pembangunan bangsa menuju bangsa yang maju, mandiri, dan sejahtera. (3) Fungsi penyaring, yaitu pendidikan karakter berfungsi memilah budaya bangsa sendiri dan menyaring budaya bangsa lain yang tidak sesuai dengan nilai-nilai budaya dan karakter bangsa yang bermartabat.

Terdapat 18 nilai karakter bangsa yang dapat dikembangkan melalui pendidikan karakter bangsa. Karakter bangsa tersebut yaitu religius, jujur, toleransi, disiplin, kerja keras, kreatif, mandiri, demokratis, rasa ingin tahu, semangat kebangsaan, cinta tanah air, menghargai prestasi, bersahabat/komunikatif, cinta damai, gemar membaca, peduli lingkungan, peduli sosial, dan tanggung jawab. Akar dari tindakan baik maupun buruk yaitu karakter. Karakter dikatakan baik dapat memberikan kemampuan kepada manusia untuk hidup bersama dalam keadaan damai serta membentuk dunia yang dipenuhi dengan kebaikan.

Mustari (2017:85) mengatakan rasa ingin tahu adalah sikap dan tindakan yang selalu berupaya untuk mengetahui lebih mendalam dan meluas dari apa yang dipelajarinya, dilihat, dan didengar. Kuoritas atau rasa ingin tahu (Mustari, 2017:85-86) adalah emosi yang dihubungkan dengan perilaku mengorek secara alamiah seperti eksplorasi, investigasi, dan belajar. Rasa ingin tahu terdapat pada pengalaman manusia dan binatang. Istilah itu juga dapat digunakan untuk menunjukan perilaku itu sendiri yang disebabkan oleh emosi ingin tahu. Karena emosi ini mewakili kehendak untuk mengetahui hal-hal baru, rasa ingin tahu bisa diibaratkan "bensin" atas "kendaraan" ilmu dan disiplin lain dalam studi yang dilakukan oleh manusia.

Berdasarkan pengertian diatas dapat disimpulkan bahwa karakter rasa ingin tahu merupakan kemampuan bawaan makhluk hidup yang mewakili kehendak untuk mengetahui hal-hal yang baru dengan tujuan untuk mengembangkan kemampuan peserta didik.

Menurut Daryanto ( 2013: 138,147) indikator rasa ingin tahu sebagai berikut : (1) Indikator sekolah yaitu : a. Menyediakan media komunikasi atau informasi ( media cetak atau media elektronik ) untuk berekspresi bagi warga sekolah, b. Menciptakan suasana kelas yang mengundang rasa ingin tahu,c. Eksplorasi lingkungan secara terprogram. (2) Indikator Siswa yaitu : a. Bertanya atau membaca sumber diluar buku teks tentang materi yang terkait dengan pembelajaran, b. Membaca atau mendiskusikan gejala alam yang baru terjadi, c. Bertanya tentang beberapa peristiwa alam, sosial, budaya, ekonomi, politik, dan teknologi yang baru di dengar, $d$. Bertanya tentang sesuatu yang terkait dengan materi pelajaran diluar yang dibahas di kelas.

Literasi dalam Kamus Besar Bahasa Indonesia memiliki arti, yaitu kesanggupan atau kemampuan membaca dan menulis. Menurut Dewi Utama (2016 : 02) Kegiatan Literasi dapat diartikan sebagai kegiatan mengakses, memahami, dan mengunakan sesuatu secara cerdas melalui berbagai aktivitas antara lain membaca, melihat ,menyimak, menulis atau berbicara. Menurut pendapat yang diutarakan oleh Bukhori (2005) dalam Marfu'i R (2016) menyatakan bahwa literasi memiliki arti sebagai kemampuan seseorang dalam menggunakan informasi tertulis maupun dari media cetak sebagai sarana untuk mengembangkan pengetahuan sehingga mendatangkan manfaat bagi semua pihak. Keterampilan literasi memiliki pengaruh 
penting bagi keberhasilan generasi muda. Keterampilan literasi yang baik akan membantu generasi muda dalam memahami informasi baik lisan maupun tertulis. Dalam kehidupan, penguasaan literasi pada generasi muda sangat penting dalam mendukung kompetensikompetensi yang dimiliki.

Untuk mengembangkan sekolah sebagai organisasi pembelajaran, Kementrian Pendidikan dan Kebudayaan mengembangkan kegiatan literasi dengan membuat sistem Gerakan Literasi Sekolah (GLS). GLS adalah upaya menyeluruh yang melibatkan semua warga sekolah (guru, peserta didik, orangtua/wali murid) dan masyarakat, sebagai bagian dari ekosistem pendidikan. Gerakan Literasi Sekolah ini memperkuat gerakan penumbuhan budi pekerti sebagaimana dituangkan dalam Peraturan Menteri Pendidikan dan Kebudayaan Nomor 23 Tahun 2015. Salah satu program di dalam gerakan tersebut adalah "kegiatan 15 menit membaca buku non pelajaran sebelum waktu belajar dimulai".

Dalam prinsip kegiatan literasi yang dikemukakan oleh Kern (2000) dalam Riandika Marfu'i (2016:5-6) meliputi tujuh prinsip yang dilibatkan dalam kegiatan literasi, yaitu:

1. Interpretasi

Penerima informasi atau komunikan, Penulis atau pembicara, dan pembaca atau pendengar melakukan interpretasi terhadap suatu hal yang diterima dan dilihatnya di mana hal tersebut merupakan sebuah peristiwa, pengalaman, ataupun suatu gagasan dalam bentuk konsepsi.

2. Kolaborasi

Dalam pembelajaran literasi melibatkan prinsip kolaborasi, di mana dalam prinsip ini terjadi kerjasama antara dua pihak yakni penulis/ pembicara dan membaca/ pendengar. Kerjasama dalam prinsip pembelajaran literasi ini menyangkut upaya dalam mencapai suatu pemahaman bersama agar sepemikiran antar kedua belah pihak.

3. Konvensi

Penulis maupun pembaca menginterpretasikan apa yang ia simak dalam sebuah bacaan yang disesuaikan dengan kesepakatan atau berupa konvensi kultural atau tidak bersifat universal dan berkembang dengan adanya modifikasi serta penggunaan informasi berupa bacaan tersebut untuk kepentingan individual. Konvensi tersebut berupa aturan tertulis maupun tidak tertulis.

4. Pengetahuan Kultural.

Penekanan dalam pengetahuan kebudayaan sangat berarti penting dalam prinsip literasi. Hal ini juga membutuhkan penginterpretasian secara mendalam serta membutuhkan kemampuan berpikir kritis dalam membaca dan menulis atau menyimak dan berbicara berfungsi dalam bersikap, memutuskan keyakinan, menunjukkan kebiasaan, dan nilai atau norma tertentu. Jika hal ini tidak disikapi dengan berpikir kritis dapat mengakibatkan rentan terkena konflik dalam suatu daerah akibat bias budaya.

5. Pemecahan Masalah.

Dalam prinsip-prinsip sebelumnya pada poin 1-4 terdapat kegiatan menyimak, berbicara, membaca, dan menulis yang juga melibatkan upaya membayangkan hubungan-hubungan di antara katakata, frase-frase, kalimatkalimat, unit-unit makna, serta teks-teks. Upaya membayangkan atau memikirkan dan mempertimbangkan ini merupakan suatu bentuk penelaahan dalam melakukan pemecahan masalah.

6. Refleksi Diri.

Pembaca atau pendengar dan penulis atau pembicara memikirkan bahasa yang erat hubungannya dengan diri mereka sendiri. Setelah mereka berada dalam situasi komunikasi, mereka akan memikirkan apa yang telah mereka katakan, bagaimana mengatakannya, dan mengapa mengatakan hal tersebut sesuai dengan pemahaman dirinya.

7. Penggunaan Bahasa.

Literasi tidak hanya berpaku pada sistem-sistem bahasa (lisan ataupun tulisan), melainkan membutuhkan pengetahuan tentang bagaimana bahasa itu digunakan baik dalam konteks lisan maupun tulisan untuk menciptakan sebuah wacana.

Pada beberapa poin diatas yang mengungkapkan prinsip kegiatan literasi dapat disimpulkan bahwa kegiatan literasi merupakan kegiatan memahami dan mencari informasi dengan cara membaca, mendengarkan dan melihat dalam pembelajaran literasi melibatkan interpretasi, kolaborasi, konversi, pengetahuan kultural, pemecahan masalah, refleksi diri, serta melibatkan penggunaan bahasa.

Siswa kelas V sekolah dasar masuk pada tahapan operasional konkret. Dimana pada tahap ini, mulai berkembang kemampuan-kemampuan berfikir secara logis dalam menghadapi persoalan yang bersifat konkret, anak belum mampu menyelesaikan masalah dengan baik 
tanpa bahan yang konkret. Pada tahap ini anak mulai menemukan diri sendiri dengan kegiatan menyelidik, mencoba, dan berekdperimen serta memiliki rasa ingin tahu yang besar.

\section{Metode}

Penelitian ini menggunakan pendekatan kualitatif jenis deskriptif dimana data yang dihasilkan berupa deskripsi atau kata-kata secara mendalam untuk menggambarkan fenomena-fenomena yang terjadi di lapangan. Menurut Moleong (2017:6) penelitian kualitatif adalah penelitian yang bermaksud untuk memahami fenomena tentang apa yang dialami oleh subyek penelitian misalnya perilaku, persepsi,motivasi,tindakan dll, secara holistik, dan dengan cara deskripsi dalam bentuk kata-kata dan bahasa, pada suatu konteks khusus yang alamiah dan dengan memanfaatkan berbagai metode alamiah. Pendekatan penelitian yang digunakan dalam penelitian ini disesuaikan dengan tujuan penelitian yaitu menganalisis dan mendeskripsikan pembentukan karakter rasa ingin tahu siswa melalui kegiatan literasi di sekolah. Dengan penerapan pendekatan kualitatif deskriptif untuk meneliti suatu masalah yang sedang berlangsung, diharapkan dapat diperoleh informasi yang tepat dan gambaran yang lengkap mengenai masalah yang diteliti.

Lokasi Penelitian ini dilaksanakan di SD Negeri Klampok 01 Kecamatan Wanasari Kabupaten Brebes yang terletak di Jalan Raya Klampok No.4 Desa Klampok Kecamatan Wanasari Kabupaten Brebes Jawa Tengah. Penelitian ini telah dilaksanakan pada semester dua Tahun Pelajaran 2018/2019 pada bulan April Selama kurang lebih satu minggu mulai dari tanggal 29 April - 6 Mei 2019. Untuk subyek pada penelitian ini adalah Guru kelas VA ibu Siti Kholisoh, S.Pd dan VB ibu Umayah, S.Pd.SD serta seluruh siswa kelas lima yang berjumlah 45 siswa.

Penelitian ini berisi data berupa kata-kata, keterangan, gambar, dan simbol yang diperoleh dari narasumber. Sumber data yang digunakan dalam penelitian ini berupa : (1) Person yaitu sumber data yang bisa memberikan data berupa jawaban lisan wawancara atau jawaban tertulis melalui angket yaitu berupa informan dalam penelitian. Informan dalam penelitian ini yaitu kepala sekolah, guru kelas V, dan peserta didik kelas V di SD N Klampok 01 Brebes; (2) Place yaitu sumber data yang menyajikan tampilan berupa keadaan diam dan gerak, yaitu kegiatan literasi, fasilitas dan sarana penunjang kegiatan literasi yang ada di SD Negeri Klampok 01 Brebes; (3) Paper yaitu sumber data yang menyajikan tanda-tanda berupa huruf, angka, gambar, atau simbol. Hal ini berupa dokumen sekolah yang berkaitan dengan profil SD Negeri Klampok 01 Brebes. Dengan sumber data tersebut penelitian ini menggunakan instrumen penelitian berupa lembar observasi, lembar wawancara, lembar angket, dan dokumentasi. Hasil data yang di peroleh diolah dan disajikan secara deskriptif kualitatif.

Dalam Sugiyono (2017:224) Teknik pengumpulan data merupakan langkah yang paling strategis dalam penelitian, karena tujuan utama dari penelitian adalah mendapatkan data. Tanpa mengetahui teknik pengumpulan data, maka penulis tidak akan mendapatkan data yang memenuhi standar data yang ditetapkan. Berdasarkan pada teori tersebut penulis menggunakan teknik pengumpulan data yaitu metode observasi, wawancara, angket dan dokumentasi.

Dalam penelitian ini subyeknya adalah siswa kelas V SD Negeri Klampok 01 Brebes setelah dilaksanakannya kegiatan literasi. Dengan cara ini akan memperoleh hasil pengamatan mengenai karakter rasa ingin tahu siswa melalui kegiatan literasi yang dilaksanakan setiap hari 15 menit sebelum memulai jam pelajaran.

Penelitian ini menggunakan wawancara semi-terstruktur. Menurut Sugiyono (2017:233) wawancara semi-terstruktur adalah jenis wawancara yang termasuk dalam kategori in-dept interview, dimana dalam pelaksanaannya lebih bebas bila dibandingkan dengan wawancara terstruktur. Tujuan dari wawancara jenis ini adalah untuk, menemukan permasalahan secara lebih terbuka, dimana pihak yang diajak wawancara diminta pendapat, dan ide-idenya. Dalam melakukan wawancara penulis perlu mendengarkan secara teliti dan mencatat apa yang dikemukakan oleh informan. Penulis melakukan wawancara guru kelas $\mathrm{V}$, dan beberapa siswa kelas V SD N Klampok 01 Brebes, sehingga penulis bisa menemukan pembentukan karakter rasa ingin tahu melalui kegiatan literasi yang ada.

Angket yang digunakan dalam penelitian ini adalah angket tentang pembentukan karakter rasa ingin tahu. Peserta didik diminta untuk merespon setiap pertanyaan maupun pernyataan sesuai dengan keadaan diri yang diketahui dengan cara membubuhkan 
tandacentang ( $v$ ) pada alternatif jawaban yang tersedia. Objek pada penelitian ini adalah peserta didik kelas V SD Negeri Klampok 01 Brebes.

Penulis menggunakan dokumen tulisan berupa, data profil sekolah, prasarana sekolah, data guru-guru dan karyawan di SD Negeri Klampok 01 Brebes. Sedangkan dokumen gambar berupa foto-foto kegiatan selama penelitian berlangsung.

Berbagai cara dalam pengecekan keabsahan data untuk menggunakan uji kredibilitas data atau kepercayaan terhadap data hasil penelitian kualitatif. Dalam penelitian ini menggunakan perpanjangan pengamatan, meningkatkan ketekunan,triangulasi, menggunakan bahan referensi.

Analisis data adalah proses mengorganisasikan dan mengurutkan data ke dalam pola, kategori, dan satuan uraian dasar sehingga dapat ditemukan tema dan dapat dirumuskan hipotesis kerja seperti yang disarankan oleh data (Moeloeng, 2017:280).Pada tahapan ini, penulis melakukan pengumpulan data-data yang dibutuhkan seperti data hasil wawancara,observasi dan angket penelitian di SD Negeri Klampok 01 Brebes, setelah mengumpulkan data-data yang di perlukan peneliti mereduksi data dengan cara memilah, membandingkan, mengurangi atau menambahkan data-data yang telah di peroleh, yang ketiga yaitu mendisplaykan data atau menyajikan data yang berupa hasil wawancara guru dan siswa kelas $\mathrm{V}$ dengan menggunakan teks naratif. Kemudian yang keempat yaitu membuat kesimpulan serta verifikasi data yang diperoleh. Moleong (2017:127) berpendapat bahwa ada tiga tahap kegiatan yang harus dilakukan oleh peneliti yaitu: tahap pra - lapangan, tahap pekerjaan lapangan, tahap analisis data.

\section{Hasil dan Pembahasan}

Berdasarkan penjabaran mengenai hasil temuan yang telah dilakukan oleh penulis pada tanggal 29 april - 6 Mei 2019, tentang pembentukan karakter rasa ingin tahu melalui kegiatan literasi pada siswa kelas V SD Negeri Klampok 01 Brebes ini dapat penulis analisis beberapa faktor mendukung maupun menghambat dalam pelaksanaannya.Penulis berpendapat bahwa sarana prasarana dan warga sekolah sangat berpengaruh dalam membentuk karakter peserta didik. Sarana prasarana yang terdapat di SDN Klampok 01 Brebes sudah dapat di katakan layak dan memadai, sehingga untuk memenuhi kegiatan pembelajaran ataupun literasi sudah baik. Berdasarkan pengamatan penulis warga sekolah baik guru dan para staf sudah memberikan contoh karakter yang baik kepada peserta didik, dengan guru berpakaian rapi dan bertingkah laku dengan baik di wilayah sekolah. Pembiasan yang dilakukan setiap hari secara tidak langsung dapat membuat pola kebiasaan kepada siswa. Pembiasaan perilaku baik ini telah di jadikan sebagai budaya dalam keseharian, sehingga siswa terbiasa melihat dan secara tidak langsung akan tersugesti untuk melakukan itu. Salah satu bentuk perilaku baik adalah budaya $5 S$ yang diterapkan di sekolah

Dalam pengamatan yang telah dilakukan penulis dalam kegiatan literasi, guru sudah melaksanakan kegiatan literasi dengan baik, hal ini juga di ikuti oleh peserta didik mengikuti kegiatan tersebut dengan nyaman, fasiilitas yang disediakan sekolah juga sudah cukup memadai sebagai penunjang kegiatan literasi. Berdasarkan hasil penelitian yang diperoleh peneliti, di dapatkan bahwa pembentukan karakter siswa tidak hanya di dapatkan dari kegiatan literi. Namun masih banyak upaya lain yang dilakukan oleh guru untuk membentuk nilai karakter pada anak, salah satu upaya guru untuk membentuk karakter siswa dengan adanya program ramah anak yang sudah lama dilaksanakan di sekolah tersebut, pembiasaan-pembiasaan lainnya juga ikut serta dalam membentuk karakter peserta didik.

Dalam pelaksanaan kegiatan literasi dalam membentuk karakter rasa ingin tahu siswa kelas $\mathrm{V}$ juga dapat penulis lihat dari hasil persebaran angket dan juga wawancara siswa kelas V. Berdasarkan hasil angket dapat peneliti simpulkan bahwa indikator dari karakter rasa ingin tahu dalam sudah berjalan cukup baik, hal ini dapat dilihat dari hasil angket yang telah di isi oleh peserta didik kelas V SD Negeri Klampok 01 Brebes. Hasil angket menunjukan bahwa siswa gemar membaca dan hal ini berpengaruh pada karakter rasa ingin tahu siswa. Selain menggunakan angket mengenai pembentukan karakter rasa ingin tahu siswa kelas $\mathrm{V}$, penulis juga melakukan pengamatan dan wawancara peserta didik kelas $\mathrm{V}$. Dalam persebaran angket dapat penulis simpulkan bahwa indikator karakter rasa ingin tahu sudah terlaksana dengan baik dan mayoritas sudah menjalankannya tetapi masih ada indikator yang perlu di tingkatkan lagi.

Pada indikator yang pertama berbunyi "Bertanya atau membaca sumber diluar buku teks tentang materi yang terkait dengan pembelajaran" siswa sudah menujukan karakter rasa ingin tahunya dengan adanya siswa yang aktif membaca dan bertanya mengenai materi 
pembelajaran yang sedang diajarkan oleh guru, walaupun masih ada beberapa siswa yang malu untuk bertanya. Masih ada beberapa pernyataan yang masih persentasenya masih rendah. Seperti pada pernyataan yang ketiga yaitu "saya berusaha mencari buku lain apabila materi pelajaran yang dipelajari tidak dapat dibuku tematik" dalam pernyataan tersebut masih ada beberapa siswa yang tidak mau atau tidak berusaha mencari referensi lain.

Pada indikator yang kedua yaitu "Membaca atau mendiskusikan gejala alam yang baru terjadi" siswa sudah menunjukan karakter rasa ingin tahu mereka dengan membaca maupun berdiskusi tentang gejala alam yang terjadi di wilayah sekitar mereka, walaupun masih ada penyataan yang persentasenya masih rendah yaitu pernyataan kesepuluh "saya membaca koran atau berita tentang peristiwa alam yang sedang terjadi di wilayah sekitar" masih banyak siswa yang memilih tidak pernah membaca, karena koran cenderung membosankan dan jarang siswa mau membaca berita yang ada di koran.

Pada indikator ketiga berbunyi "Bertanya tentang beberapa peristiwa alam, sosial, budaya, ekonomi, politik, dan teknologi yang baru di dengar" bahwa siswa sudah mulai bertanya mengenai budaya maupun sosial diwilayah sekitar maupun dalam pembelajaran, tetapi ada pernyataan yang masih rendah persentasenya yaitu pernyataan keduapuluh yaitu "saya lebih memilih diam jika kurang memahami materi pembelajaran" disini dapat disimpulkan bahwa masih ada beberapa siswa yang lebih memilih diam walaupun pembelajaran dirasa kurang jelas.

Pada indikator keempat berbunyi "Bertanya tentang sesuatu yang terkait dengan materi pelajaran diluar yang dibahas di kelas" pada indikator tersebut siswa sudah menunjukan karakter rasa ingin tahunya dengan siswa bertanya mengenai materi di luar jam pembelajaran, contohnya bertanya dengan orang tua saat berada dirumah, dan saat berada di sekolah siswa bisa bertanya dengan guru maupun teman sebaya mereka. Tetapi masih ada pernyataan yang persentasenya rendah yaitu pernyataan keduapuluhdua yaitu "jika ada sesuatu diluar kelas yang membuat saya penasaran, saya enggan bertanya pada teman maupun guru" pada pernyataan tersebut masih ada banyak siswa yang lebih memilih mengetahuinya sendiri dan tidak bertanya pada teman maupun guru.

Berdasarkan uraian diatas dari sebelum adanya kegiatan literasi, siswa dirasa masih monoton didalam kelas, dan tidak memiliki wawasan yang pengetahuan yang tinggi, tetapi setelah dilaksanakannya kegiatan literasi siswa lebih aktif dalam membaca buku yang mereka sukai, wawasan mereka juga luas dan mereka dapat mengetahui banyak buku cerita maupun yang lainnya. Kegiatan literasi juga mengembangkan karakter siswa, salah satunya karakter rasa ingin tahu siswa mengalami peningkatan. Dalam kegiatan ini penelitian tidak hanya dilakukan menggunakan wawancara dan angket, akan tetapi penulis juga mengamati upayaupaya guru sebagai model pendidikan karakter dalam hal ini sudah sesuai dengan apa yang diharapkan dan diteladani bagi siswa kelas V di SD Negeri Klampok 01 Brebes. Hal ini dilakukan supaya hasil yang di peroleh lebih valid. Dari data penelitian yang di peroleh, dapat disimpulkan bahwa kegiatan literasi membaca berpengaruh pada karakter rasa ingin tahu siswa.

Dari hasil analisis data penelitian diketahui bahwa kegiatan literasi sesuai dengan program Penguatan Pendidikan Karakter ( PPK ). Hal ini karena literasi merupakan salah satu kegiatan untuk mencapai tujuan dari PPK. Pendidikan karakter siswa dibagi menjadi beberapa rumpun, salah satunya adalah pendidikan karakter rasa ingin tahu. Perwujudan karakter individu berasal dari hasil integrasi empat bagian karakter bangsa yang sesuai prinsip pancasila dikembangkan dari buku Desain Induk Pembangunan Karakter Bangsa 2010-2025 (Pemerintah Republik Indonesia, 2010) antara lain olah hati,olah pikir, olah rasa dan olah raga. Dari perwujudan karakter individu tersebut rasa ingin tahu termasuk dalam perwujudan olah pikir. Sehingga kegiatan literasi berpengaruh pada pencapaian tujuan PPK.

\section{Simpulan Dan Saran}

This Berdasarkan hasil pengamatan mengenai kegiatan pembentukan karakter rasa ingin tahu melalui kegiatan literasi pada siswa kelas V di SD Negeri Klampok 01 Brebes melalui lembar observasi yang dilakukan di 2 kelas yakni kelas kelas VA dan VB diperoleh kesimpulan bahwa aspek rasa ingin tau siswa baik dalam pembelajaran atau hal-hal diluar kegiatan pembelajaran telah terbentuk dari kegiatan literasi membaca 15 menit sebelum pembelajaran. Hal ini dibuktikan pengamatan peneliti terhadap kegiatan yang dilakukan oleh siswa. Siswa sangat antusias dengan kegiatan literasi membaca 15 menit sebelum pembelajaran, antusias 
seperti ini juga berpengaruh pada karakter rasa ingin tahu yang ditunjukan dari perilaku siswa sehari-hari.

Dari data hasil angket yang telah diisi oleh responden dapat dilihat hasil tertinggi sebanyak $86,7 \%$ yaitu siswa menjawab "Tidak Pernah" pada pernyataan ke 14 "Saya tidak peduli saat wilayah Brebes terkena musibah", dan pernyataan ke 18 "Saya lebih memilih bermain dan tidak peduli jika ada teman yang kesusahan". Dari data hasil wawancara penulis dengan Guru kelas dan Siswa kelas $V$ untuk pelaksanaan kegiatan literasi sudah berjalan dengan baik walaupun masih memiliki kekurangan dari segi sarana prasarana maupun guru. Siswa merespon dengan positif pelaksanaan kegiatan literasi tersebut.

Hasil wawancara dengan kedua narasumber guru mengenai pendidikan karakter rasa ingin tahu, mengungkapkan bahwa pendidikan karakter sangat penting dan sedang digalakkan di sekolah. Salah satunya yakni pembentukan rasa ingin tahu melalui kegiatan literasi membaca 15 menit sebelum kegiatan pembelajaran. Melalui kegiatan membaca siswa memiliki pengetahuan luas yang menimbulkan rasa penasaran atau rasa ingin tahu. Mereka mengungkapkan dari kegiatan literasi yang dilakukan secara rutin siswa menjadi keranjingan membaca. Selain itu mereka menjadi sering bertanya ketika tidak memahami sesuatu yang dibaca atau hal-hal yang baru diketahui. Rasa ingin tahu mereka tidak hanya mengenai materi pembelajaran, tetapi juga mengenai kejadian alam yang ada disekitarnya. Secara keseluruhan yang telah dilakukan dapat diketahui bahwa kegiatan literasi membaca 15 menit sebelum pembelajaran dapat membentuk program penguatan pendidikan karakter (PPK) khususnya karakter rasa ingin tahu pada siswa.

\section{Daftar Pustaka}

Abidin Y, dkk. 2018. Pembelajaran Literasi Strategi Meningkatkan Kemampuan Literasi Matematika, Sains, Membaca, dan Menulis. Jakarta: Bumi Aksara.

Arikunto S. 2010. Prosedur Penelitian Suatu Pendekatan Praktik. Jakarta : PT Rineka Cipta.

Ayu, Nanda . 2017. Pendidikan Karakter Sebagai Pilar Pembentukan Karakter Bangsa . Jurnal Fakultas Ilmu Sosial Universitas Negeri Medan Tahun 2017 Vol. 1 No. 1 2017, Hal. 348352

Daryanto dan Darmiatun S. 2013. Implementasi Pendidikan Karakter di Sekolah. Yogyakarta:Gava Media.

Faizah, Dewi Utama dkk. 2016. Panduan Gerakan Literasi Sekolah di Sekolah Dasar. Jakarta: Direktorat Jendral Pendidikan Dasar Dan Menengah Kementrian Pendidikan Dan Kebudayaan.

Fauzi AR, dkk. Penguatan Karakter Rasa Ingin Tahu dan Peduli Sosial Melalui Discovery Learning. E-journal UNM.http://journal2.um.ac.id/index.php/jtppips/article/view/2500. Diunduh pada 20 Oktober 2018.

Hasan, S.H., dkk. 2010. Pengembangan Pendidikan Budaya dan Karakter Bangsa.Jakarta: KEMENDIKNAS.

Kesuma Dharma, dkk . 2012. Pendidikan Karakter Kajian Teori dan Praktik di Sekolah. Bandung : PT Remaja Rosdakarya.

Kurniawan S. 2017. Pendidikan Karakter Konsepsi dan Implementasinya Secara Terpadu di Lingkungan Keluarga, Sekolah, Perguruan Tinggi, dan Masyarakat.Yogyakarta:Ar Ruzz Media.

Marfu'i L.N.R. 2016. Upaya Pendukung Pembelajaran Literasi Dengan Mengasah Kemampuan Berpikir Kritis Melalui Teknik Bibliolearning Pada Siswa. E-Journal UTP. http://ejournal.utp.ac.id/index.php/JMSG/article/view/476. Diunduh pada 16 Januari 2019.

Moleong L.J. 2017. Metodologi Penelitian Kualitatif . Bandung : PT Remaja Rosdakarya. 
IVCEJ, Vol 2 No 2, Tahun 2019

p-ISSN: 2615-4684 e-ISSN: 2615-6938

Muslich M. 2011. Pendidikan Karakter Menjawab Tantangan Krisis Multidimensional.Jakarta: PT Bumi Aksara.

Mustari M.2017. Nilai Karakter Refleksi Untuk Pendidikan. Depok : Raja Grafindo Persada.

Omeri, Nopan. 2015. Pentingnya Pendidikan Karakter Dalam Dunia Pendidikan. Manajer Pendidikan, Volume 9, Nomor 3, Juli 2015, hlm. 464-468

Puspitasari MT, dkk. 2015. Upaya Meningkatkan Karakter Rasa Ingin Tahu dan Hasil Belajar Akuntansi Melalui Pembelajaran Kontekstual dengan Metode Snowball Throwing Pada Siswa SMK Muhammadiyah Gemolong. Jurnal Tata Arta UNS. file:///C:/Users/user/Downloads/6309-13433-1-SM.pdf . Diunduh pada 10 Maret 2019.

Setianingsih ES, dkk.2018. Perkembangan Peserta Didik.Semarang: Universitas PGRI Semarang.

Silmi M dan Kusmarni Y. 2017. Menumbuhkan Karakter Rasa Ingin Tahu Siswa Dalam Pembeljaran Sejarah Melalui Media Puzzle.E-journal UPI . http://ejournal.upi.edu/index.php/factum/article/view/9980. Diunduh pada 20 Oktober 2018.

Sugiyono. 2017. Metode Penelitian dan Pengembangan Research and Development. Bandung : Alfabeta.

Syarbini A. 2017. Pendidikan Karakter Berbasis Keluarga: Studi Tentang Model Pendidikan Karakter dalam Keluarga Perspektif Islam.Yogyakarta:Ar Ruzz Media.

Wibowo A.2012.Pendidikan Karakter Strategi Membangun Karakter Bangsa Berperadaban.Yogyakarta.Pustaka Pelajar. 